\title{
THE INFORMATISATION OF PUBLIC ADMINISTRATION IN POLAND FROM THE POINT OF VIEW OF INDUSTRY AND SUSTAINABLE LOCAL DEVELOPMENT
}

\author{
Magdalena SiteK ${ }^{1}$, Iwona FloreK ${ }^{2}$, BronisŁaw SiteK ${ }^{3}$ \\ University of Euroregional Economy in Józefów-Warsaw (Poland) \\ SWPS University of Social and Humanities Science in Warsaw (Poland)
}

\begin{abstract}
The subject of this study is to present the process of implementing the concept of e-citizen in Poland in the perspective of industry 4.0. In the global world, a significant part of public administration, including local government administration, aims to increase activity using Information and Communication Technology. This process allows introducing more efficient functioning of public administration, especially in the scope of providing services to the citizen. Changes in the functioning of public administration are forced by changes in ICT, in particular by those resulting from the current implementation of the concept of industry 4.0.

The result of the research was a description not only the legal bases or development policies of public e-administration, but first and foremost to indicate its practical implementation effects. As part of the practical effects, the study will present examples of the effects of e-administration implementation in the Otwock County. In particular, the attention will be paid to the implementation of elements of computerization of administration by the local authorities, and how it affects local sustainable development.

KEYWORDS: Informatization, Public Administration, Industry 4.0, Poland
\end{abstract}

JEL CODES: D83, H83

DOI:

\section{Introduction}

The term 'administration' is derived from the Latin word ministrare, which means service, performance of activity subordinated to orders (Kaczmarski, 2009, 220). Thus, by definition, administration is not needed "for itself", but is intended to achieve goals (cf. Kaniewska, Klimski, 2017, 283 the tasks of the government are to serve and fulfill needs, ex. eradicting poverty). Public administration should therefore be a tool used to perform public tasks, imperious tasks assigned by the legal order to the state and its organs or other entities performing imperious functions (Encyclopedia PWN). In a law-abiding state, the activities of public administration entering the sphere of rights and obligations of the citizen and other entities not subordinated to public administration must be based on the authorization of the law, although modern state and self-government administration performs tasks that go beyond the function of exercising the law (e.g. satisfying the collective needs of society).

1 Assoc. prof. Hab. Dr.Magdalena Sitek- Alcide De Gasperi University of Euroregional Economy. Scientific interests: Law, public administration

e-mail: ms@wsge.edu.pl

Phone: +48227891903

2 Dr. Iwona Florek - Alcide De Gasperi University of Euroregional Economy. Scientific interests: Law, public administration. e-mail: iwona@wsge.edu.pl

Phone: +48 227891903

3 Prof. Hab. Dr.Bronisław Sitek- SWPS University. Scientific interests: Law, public administration.

e-mail: bronislaw.sitek@gmail.com

Phone: +48 881300003 
The idea and purpose of public administration as a service to fulfill the supreme goal of the state, which is not only survival at the present time, but development giving the chance for further flourishing of the state, serving the needs of the present generation and taking into account the needs of future generations, is worth comparing with the concept of sustainable development, i.e. development ensuring equal treatment of three different aspects: economic development of the state, ecological activity, including rational use of natural resources and social aspect ensuring that the needs of residents are met.

At the same time, for sustainable development, as for any other idea, it is apt to say 'think global, act local'. This local level seems to be the most appropriate for initiating sustainable development. And here, local government plays a special role in the process of sustainable development. This is due both to the nature as the host of the area, as well as to statutory obligations that impose tasks on the local government in the field of shaping the local living environment. Only local government structures are able to direct local development to solve the basic socio-economic problems of a given territorial unit and guarantee the primacy of the general public over individual interest (Parysek, 2001, 214). Sustainable development at the local level will mean, in particular: matching local skills and needs to employment availability, environmental protection based on an ecosystem approach to minimizing the use of natural resources, waste production and emissions, satisfying local needs taking place at the local level, participation of all local sectors, communities in local planning and decision-making, high quality and universal access to basic services, and high quality of the cultural heritage (Borys, 2005, 73).

The authors assume that informatizaion of administration is only a mean of implementing the concept of sustainable development using available and widespread technologies thanks to the spread of industry 4.0. In this perspective, the research problem is defined as presenting the assumptions of e-administration as a tool for residents and other recipients of public administration services, which is also the result of the IT revolution and the concept of sustainable development, i.e. economic and ecological and social balance that takes into account the needs of present and future generations.

As a result of this goal, the authors drew conclusions about the level of implementation of electronic administration, in particular dealing with citizens' matters in the Otwock County.

In this perspective, it would seem, the process of computerization of public administration, i.e. the process of digitization, implementation of new information, telecommunications and teletechnical technologies should be understood. The computerization of public administration should enable better, smoother, more efficient, faster and more effective realization of the needs by public administration using imperious power of the state for both individual recipients, i.e. residents and entrepreneurs.

\section{Computerization of public administration}

in the European Union and Poland - historical outline

Information technology has become one of the crucial elements of managerial reforms and electronic government (e-government) may figure prominently in the future government. New technologies have opened up many possibilities for improving internal managerial efficiency and the quality of public service delivery to citizens. IT has contributed to vivid changes in politics, government institutions, performance management etc. (Moon, 2002, 424).

The European Union has already dealt with the concept of electronic administration over twenty years ago. In 1997 the Commission of the European Communities issued Green Paper on the Convergence of the Telecommunications, Media and Information Technology Sectors, and the Implications for Regulation (1997) a document that analyzed the convergence phenomenon - its technological underpinnings, current developments, and their possible impact on the telecommunications, media and information technology sectors.

In 1999, the European Commission presented the eEurope initiative (COM(1999)687), which suggested the need to provide every EU citizen, every school, all enterprises and offices with access to new ICT technologies and their use (Kaczorowska, 2008, 526). The document was an introduction to one of priorities of key document of European Union on which the process of building a European information society is based, 
i.e. the so-called Lisbon strategy adopted in 2000, assuming the creation by 2010 of "the most competitive and dynamic economy in the world, based on knowledge, capable of sustainable development and providing more and better jobs and greater social cohesion." The strategy was to create an online administration, and the actions taken in this direction were to focus mainly on providing effective and easy access to administration publicly by electronic means. The adopted strategy should therefore be seen as a foundation for future development activities "informatization" of public administration activities. However, only two years later, in the documents of Commission of the European Communities, E-Europe 2002 only 1 out of 6 measures to achieve the goal of eEurope is "legislation on the distance marketing of financial services, the application of VAT to electronic commerce and the use of electronic invoicing for VAT purposes ". Other measures do not apply to public administration (European Communities, $2001 \mathrm{a}, \mathrm{b}$ ).

After adoption of Lisbon Strategy, in 2005 a review of the Lisbon Strategy was carried out, resulting in the initiative "i2010 - European information society for growth and employment." It assumed the construction of an e-government action plan and strategic guidelines on public-based services on new information and communication techniques (Feret, 2019, 55-56).

Later-on a document concerning the development of e-government was issued by Commission: The European eGovernment Action Plan 2011-2015 Harnessing ICT to promote smart, sustainable \& innovative Government.

A strategy EUROPA 2020 - A strategy for smart, sustainable and inclusive growth is coming to the end in 2020. The goal was to ensure the economic recovery of the European Union after the economic and financial crisis and was supported by flagship initiatives at European level and in EU countries, including European Digital Agenda.

The Agenda is supported by eGovernment Action Plan 2016-2020 Accelerating the digital transformation of government (COM(2016)0179). The eGovernment action plan provides sources of information and guides to support the administrations local and regional administrations. They are the public sector's primary interface with citizens and businesses. $60 \%$ of the decisions taken by our towns and regions are influenced by European legislation. Almost $70 \%$ of public sector investments in Europe come from local and regional governments. $40 \%$ of EU funds are invested in local government (European eGovernment Action Plan 2016-2020).

The history of computerization of public administration in Poland is already several years old, it is difficult to indicate the exact date from which this process takes place. The date of April 1, 2003 can be taken as the beginning of the computerization of public administration in Poland; on that day, the Ministry of Science and Information Technology was also created on the basis of a regulation of the Council of Ministers (Dz.U. $2003 \mathrm{nr} 51$ poz. 443).

The objective in the field of computerization of public administration was recognized as an absolutely priority (i.e. of the greatest importance in the years 2003-2006) the "Polish Gate" project (an integrated platform of public administration services for the information society).

At the same time, the ePUAP project was developed - an electronic Platform for Public Administration Services (Szafrański, Weydman, 2012, 12) - i.e. a common infrastructure for integrated, unified, aggregated access to public services, which is offered, among others for trusted profile service enabling identification of the entity performing the activity (Szczerbowski, 2019, 528). Unfortunately, the plans announced in the Computerization Strategy of the Republic of Poland - ePoland for 2004-2006 remained largely on paper; The Supreme Audit Office report of the October 2006 regarding the government's computerization strategy showed various negligence in its implementation (NIK, 2006).

The most important government documents constituting the stages of development of the country's information society and the computerization of public administration can be indicated as follows:

1. Resolution of the Sejm of the Republic of Poland of July 14, 2000 on building the foundations of the information society in Poland (M.P. z 2000 r. Nr 22, poz. 448)

2. Act of 6 September 2001 on access to public information (Dz. U. z 2019 r. poz. 1429)

3. The computerization strategy of the Republic of Poland - ePoland for 2004 - 2006 of 13 January 2004

4. Act of 17 February 2005 on the computerization of entities' activities (Dz.U. z 2020 r. poz. 346). 
5. Directional strategy for the development of Poland's computerization until 2013 and a forwardlooking forecast for the transformation of the information society until 2020 in the context of the Lisbon Strategy and the i2010 Initiative of June 24, 2005 prepared by the Ministry of Science and Information Technology

6. Report State 2.0 - A new start for e-administration adopted by the Ministry of Administration and Digitization, which is a summary of the state of implementation of works and a proposal of a new approach to the problem of computerization (Kmiecik, 2015).

7. Currently the strategy is: Poland 2030. The third wave of modernity. Long-term National Development Strategy. The main purpose of the document Poland2030 is to improve the quality of life of Poles (cf. Gajowniczek, 2017, 28-40). The project emphasizes simultaneous development in three strategic areas: competitiveness and innovation of the economy, balancing the development potential of Polish regions as well as the efficiency and effectiveness of the state (Resolution No. 16 of the Council of Ministers of February 5, 2013 regarding the adoption of the Long-Term National Development Strategy. Poland 2030. Third Wave of Modernity - Monitor Polski pos. 121 z 1 March 2013)

\section{Industry 4.0 and the needs of changes in the organization} and functioning of public administration

The Fourth Industrial Revolution puts increasing expectations in front of governments resulting from the new role of the state in the economy and its involvement in solving unreliable markets (Micklethwait 2015). In this new approach, management and efficiency of state activities, both of central and local administration, are becoming the key priority. The industrial policy implemented by many countries is in fact aimed at reorienting national economies towards the fourth generation industry (Roland Berger 2016), either by preserving and restoring jobs, or by trying to improve the competitiveness and added value of domestic production.

Proponents of the view that industry 4.0 is a revolution are even inclined to the view that we are dealing with a change on such a scale that we can even talk about "life 4.0". Major changes concern not only the industry, but also the functioning of public administration, health care, the labor market, and thus such issues as: commuting, working time, organization of jobs, training, etc. (Gotz, Gracel, 2017, 223).

The fourthgeneration industry should be understood as a common term connecting technology and organization of the value added chain (collective term for technologies and concepts of value chain organization) (Hermann 2015). It assumes the existence of intelligent systems that are cross-linked - vertically connected to other processes within the enterprise / institution and horizontally associated with value-creating networks that can be managed in real time. Industry 4.0 is an intelligent combination of many IT technologies used in enterprises. It is a complex solution created at the interface of engineering, IT and management knowledge. It assumes strict computerization of traditional branches of the manufacturing industry and gradually blurs the boundary between individual sectors. Although given the fact that many of the solutions driving the fourth revolution are already working (cloud computing, Big Data), some authors believe that the observed and announced transformation is not so much a revolution as a stage of evolution of already existing solutions (Maślanek 2014; Alcácer i.in 2016). However, Klaus Schwab, one of the founders of the World Economic Forum, claims that the name, which directly refers to the three previous industrial revolutions, is misleading, because the scope of this revolution is much more extensive. The main differences between the fourth and third revolution are: worldwide access to the Internet, diametrical reduction of data storage costs (storage of $1 \mathrm{~GB}$ of data in 1995 cost approx. USD 10,000/year, in 2016 it costs 3 cents/year), mobile devices, intelligent sensors (including those responding to human presence), renewable energy sources and artificial intelligence (including machine learning) (Schwab, 2016). These technical solutions, derived from business, are gradually translated and used in public administration.

Features of cyber-physical systems (CPS) distinguishing industry 4.0, so-called six design principles and their importance for the functioning of public administration: 
- interoperability, understood as the ability to communicate with administration employees, service recipients and cyber-physical systems. For consistent and efficient cooperation between CPS systems, entire institutions and their employees (possible thanks to the Internet of Things and Services), clearly defined standards are necessary - they must be defined by law for public administration;

- visualization, the second of the design principles, means the possibility of creating a certain virtual equivalent of the real world that would be able to monitor actual physical processes;

- decentralization (understood as the ability of cyberphysical systems to operate autonomously) - reflects the tendency of increasing expectations for customized / individualized products, which implies increasing difficulties with central / top-down system of control - this principle is not applied in the currently functioning e-government model, services are not individualized, every citizen or entrepreneur has access to the same services. Although, as M. Sitek points out, one of the forms of greater integration through decentralization of public administration are government agencies and decentralization takes place through agencies (Sitek, 2016, 95). However, it has no direct impact on local governments.

- real time means that data is collected and analyzed on an ongoing basis as it occurs, allowing for faster analysis and response;

- service orientation is understood as the possibility of sharing and using the services of CPS systems and employees (thanks to the Internet of services) to other process participants, also outside the institution;

- modularity (the ability to change production characteristics by replacing or adding ready-made modules to the process) means the ability to flexibly adapt to changing requirements by replacing or extending individual modules. Modular systems may be subject to adjustment and expansion, thanks to which e.g. a citizen has access to implemented newer e-administration services (modules), e.g. e-prescriptions issued interchangeably with a traditional prescription from 2018 in Poland, and from January 2020 only this form.

Projects implemented under the auspices of public institutions change the perception of citizen service, and what is worth emphasizing, these changes are often accepted by citizens as much deeper, more serious because of the stereotypes associated with governmental or local bureaucracy and technological debt that these instances maintained for years (Such, 2019, 163).

\section{Information society and sustainable local development}

The new concept of industry operations and public administration functioning also significantly changes the concept of sustainable development. Because of those changes, a citizen can efficiently settle his or her cases without leaving home and he or she can control the administration, especially in the area of environmental protection. The process of computerization of public administration also allows for a more rational use of public funds. ICT devices allow a citizen to gain greater knowledge about the activities of central and local authorities related to the state of the environment, health protection, benefits and financial assistance.

The information or knowledge society has come into focus of the researchers. It has become the subject of extensive studies of many prominent academic centers in the world. Researchers and scholars distinguish and explore different dimensions of the information society: technological, economic, occupational, spatial and cultural, as well as ecological and social. Simultaneously, specialists have as often as possible required an all encompassing, methodological and more frameworks way to deal with the advancement of data society, covering all components of the data society (cf. Wójcicka, Łęski, 2015, 341). The sustainable information society (SIS) entails a new phase of information society development. It is critical to investigate how we can utilize data and ICTs to add to maintainable practices and procedures in contemporary social orders just as supporting administrative strategies and systems that permit organizations, governments and social orders to add to feasible turn of events. 
ICTs play a significant role in the development of information society, in particular the widespread use of ICTs by the actors (beneficiaries, stakeholders) of the information society (citizens, enterprises, public administration), but also in the development of ICTs economic sectors (Ziemba, 2013, 106-108)

O'Donnell (O'Donnell, 2003, 26) defines an inclusive information society as a society that ensures that all citizens (especially the elderly, women at home, the disabled, farmers, the unemployed, etc.) have the opportunity to use ICTs to improve the quality of their lives and communities (community-building and -maintenance, eCommerce, eBusiness, eLearning, eLeisure, eHealth, and eGovernment), to contribute to a knowledge-based economy and society (improving human capital and innovation related abilities, cultivate ICT-related financial development, increment the utilization of ICTs, unique help for ICT learning, and aptitudes for burdened people and rural zones), and to engage with government services and participate in democratic process and that civil society is engaged with the help of ICTs in ICT training, employment, democratic participation, online content production, and the building of social capital and trust in ICTs.

The Heinrich Boll Foundation defines in the Charter of Civil Rights for a Sustainable Knowledge Society a sustainable knowledge society as a society based on free access to knowledge, understood as public good owned by all, openness of technical standards and organization forms, securing privacy, cultural and linguistic diversity, diversity of the media and public opinion, the long-term conservation of knowledge, bridging the computerized divide, freedom of information as a civil right to political activity and straightforward organization, and securing freedom in workplace (Fuchs, 2010, 41).

In the context of the functioning of public administration it can be noted that a knowledge society, or information society is the one that has easy access to: public information, public authorities, public services. A citizen should expect that his case will be dealt with quickly and without undue delay while maintaining a minimum paper form and maximizing the use of available digital technologies, but also maintaining full protection of his rights when using services in cyberspace (Florek, Eroglu, 2019, 27 and Sitek, Such, 2018, 201).

The ideas of information society, sustainable development principles and administration make up the concept of electronic administration, as it i.a targets to reduce the use of paper and energy supplies to a minimum. In the European Union this process is proceeding quite vigorously, but in Poland changes are taking place slowly. As Śledziewska et al. point out Poland, on average, is lagging behind other European countries from both SMEs perspective and especially from citizens perspective in implementing effective technologies in public sector. (Śledziewska et al., 2016, 119). It is regrettable that m-govenment (mobile government - initial stage of the development of futuristic trends of the e-government) (Kanaan et al, 2019, 495) technology has not yet been introduced in Poland.

\section{Informatization of local administration on the example of the Otwock County}

Otwock County has 123,770 inhabitants, of which $52.1 \%$ are women and $47.9 \%$ are men. In the years 2002-2017 the number of inhabitants increased by $8.5 \%$. The average age of residents is 41.0 years and is comparable to the average age of residents of the Mazowieckie voivodship and comparable to the average age of residents of all of Poland. 59.6\% of Otwock County residents are of working age, $19.8 \%$ are of preworking age, and $20.6 \%$ of residents are of post-working age (Powiat Otwocki - Dane demograficzne). It means that the inhabitants are both young and middle-aged people to whom the e-services offer can be directed, as well as the elderly who will not be interested in settling matters remotely.

In the current Development Strategy of the Otwock County for 2014-2020, the development of broadband internet was indicated as the second operational objective under the fourth strategic objective (Strategia rozwoju Powiatu). The strategy justifies the choice of target with diversified Internet access, especially broadband. Nowadays it is not possible to conduct innovative business activity without access to broadband networks, and also because there are more and more e-services available, especially in the suburban areas of large cities (and this is the Otwock County), more and more high-class specialists are settling they can remotely and electronically send the results of their work, the development of broadband network in the County becomes crucial. Moreover, wider introduction of e-services (also in the field of e-health care service) is associated with access to the Internet, especially broadband. 
Currently, various activities are carried out in the County in this area, which will be continued and expanded in the following years (e.g. projects implemented with the support of EU fundings by the Otwock County in partnership with the municipalities of: Sobienie-Jeziory and Wiązowna, the commune of Celestynów, Józefów, Karczew ).

In the Strategy for Human Resources Management in the Otwock County of 2013, already in the introduction, among the basic factors influencing the situation of the State and organization, i.a. IT revolution. However, there is no reference to it in the content of the Strategy (Strategia Zarządzania Zasobami Ludzkimi, 2013). It is important to remember that human resources are extremely valuable for any organization and it would be worth investing in their development (Romaniuk, 2018, 276).

The organizational regulations of the office indicate the competence of the administrative department in the field of computerization, including computer network administration, development of the concept of computerization, selection of computer hardware and software, maintenance of computer hardware, organization of data security and protection against destruction and access of unauthorized persons (paragraph 21, item 5). However, these are not activities related to the introduction of e-services and e-administration, but only the internal activities of the office (Regulamin organizacyjny, 2016, see also Bułajewski, 2014, 285).

The County commenced the implementation of projects financed from EU funds "Acceleration of the growth of competitiveness of the Mazowieckie voivodship, by building an information society and knowledge-based economy by creating integrated knowledge bases about Mazowsze" and "Development of electronic administration in the self-governments of the Mazowieckie voivodship supporting the reduction of voivodship potential" (Uchwała nr 193/XXX/09) which should be evaluated positively. However, these are not projects implemented by the County and County is only a beneficiary. County does not implement own projects in the field of introducing innovative ICT solutions.

As part of offering e-services, "meeting the expectations of our Customers and trying to adapt the Office's activities to the highest standards of services, we introduced the possibility of contacting and dealing with some matters via the Internet" (County website). Nationwide services are offered:

- Public Information Bulletin - containing public information in electronic form, required by Polish law

- Electronic Inbox of the Vehicle and Driver System, i.e. the possibility of submitting an electronic application for issuing driving privileges and for registering vehicles,

- system for checking the status of the vehicle registration certificate and driving license

- EPUAP electronic inbox

- The Gates of Mazovia, i.e. a system for handling complaints and requests from citizens.

The introduction of the citizen's digital identity system and the digitization of many state registers, such as e.g. online access to land and mortgage registers, register of penalty points, etc., significantly facilitates the efficient functioning of state organs and everyday life of citizens (Such, 2019, 164).

The only "innovation" is allowing the payment of receivables constituting the revenues of the Otwock County budget with a different payment instrument than cash, including an instrument on which electronic money is stored, e.g. with a bank card or using mobile banking. (Uchwała 34/V/19). This was introduced in 2019, when electronic payments are already widespread everywhere, so it can be said that the County is delayed in this respect.

The Otwock County offers its residents and entrepreneurs operating in its area remote handling services for certain matters. However, these are only services offered throughout Poland, the County does not show innovation in this area, even there are many innovative ideas (cf. Rzewuski, 2013, 407-410) and the County may become a leader in its implementation. The strategic documents do not indicate the goal related to the development of e-services and further computerization, and thus facilitating official matters for clients.

This may be caused on the one hand by a lack of willingness or skills, technical and human resources, to introduce changes and facilities in the form of a wider use of ICT. On the other hand, the County is a public administration unit and as such is bound by the law, so some changes cannot be introduced by force to the citizens or entrepreneurs.

It seems that the County could make it easier for residents to participate in the decision-making process in the County, as, M. Sitek points out, the legislator is obliged to create appropriate conditions for the residents 
so that they can participate in the development of self-government both individually and in a collective form (Sitek, 2017, 145, see also: Lielpeters, 2019, 53).

It should also be noted that small businesses, self-employed persons or NGOs, but also older citizens may be reluctant to change due to a lack of digital competence.

\section{Conclusions}

E-government (electronic administration) is the use of IT tools and technologies in the public administration sector. They are aimed at simplifying communication between the applicant and the office, as well as improving the effectiveness of offices in the scope of their services, e.g. ensuring the possibility of settling matters between a citizen and a representative of the administration by electronic means or the possibility of submitting applications for the necessary documents in the same way. The European Commission defines e-Government (egovernment) as the use of information technology (the Internet and modern means of communication) in public administration. This is related to organizational changes and new skills of public services that are to improve the quality of services provided by the administration. Moreover, e-government is the implementation of the assumptions of the concept of sustainable development based on economic, social and ecological balance. Digitization not only reduces the costs of business operations by eliminating the personal delivery of documents, streamlines the process of settling matters between public authorities and the population or entrepreneurs, but also has a positive impact on the environment. This is expressed, among others in reducing paper consumption and natural resources, reducing infrastructure usage by doing things remotely.

In Poland the responsible body for digitalization of administration is Ministry of Digital Affairs. Its mission is to create a digital boost for the development of Poland. The main tasks of the new ministry are to develop broadband infrastructure, support the creation of web content and e-services and promote digital competences among citizens as well as digitalization that lies on three pillars: providing internet access, developing web content and services and promoting digital competences.

The introduction of the computerization process of the Polish administration should be assessed positively, especially in view of the changes brought by the concept of industry 4.0. The state strives to guarantee the appropriate legal, institutional and technical framework necessary for conducting business activity at the level of industry 4.0. In particular, it seeks to create an appropriate and secure broadband network infrastructure and ensure high quality, reliable connections. However, the most important action of the state that requires further action in this area is to create a regulatory framework that will allow the implementation of industry 4.0 solutions.

The appropriate activity of local government authorities, including the Otwock county reflects the activities of the central government of the state. The grounds for adapting the activities of the Otwock county to the requirements of industry 4.0 are reflected in the strategy adopted in 2013. Unfortunately, it is a rather old political act requiring fairly rapid amendment. Nevertheless, the County authorities undertake actions to implement IT programs to contact clients. However, this area of computerization of local administration requires rapid further improvement.

\section{References}

Alcácer, J., Cantwell, J., Piscitello, L. (2016). Internationalization in the information age: A new era for places, firms, and international business networks? Journal of International Business Studies, No. 47, p. 499-512.

Berger, R. (2016). The Industrie 4.0 transition quantified. How the fourth industrial revolution is reshuffling the economic, social and industrial model Roland Berger. Monachium.

Borys, T. (ed.) (2005). Wskaźniki zrównoważonego rozwoju. Białystok.

Bułajewski, S. (2014). Rola rady powiatu, zarządu powiatu i starosty w wykonywaniu zadań powiatu z zakresu bezpieczeństwa i porządku publicznego. Journal of Modern Science, Vol. 23(4), p. 285-307.

Dictionary PWN. Online: https://encyklopedia.pwn.pl/haslo/administracja;3865851.html [access: 14-04-2020].

Feret, E. (2019) Informatyzacja w samorządzie terytorialnym na przykładzie miasta Rzeszowa a zasada jawności budżetu. In M. Sitek, P. B. Zientarski (eds.). Wybrane aspekty informatyzacji w samorzadach a zasada dobrej administracji. Warszawa, p. 53-71. 
Florek, I., Eroglu, S. E. (2019). The need for the protection of human rights in cyberspace. Journal of Modern Science, Vol. 42(3), p. 27-36.

Fuchs, C. (2010). Theoretical Foundations of Defining the Participatory, Co-Operative, Sustainable Information Society. Information, Communication \& Society, Vol. 13 (1), p. 23-47. DOI: 10.1080/13691180902801585.

Gajowniczek, T. (2017). Digitization of public administration in Poland on the example of the employment and social welfare sectors. Regional Formation and Development studies, Vol. 22, No. 2, p. 28-40.

Gonciarski, W., Mazurek, I. (2014). E-administracja a Polsce - Główne założenia, stan aktualny i kierunki rozwoju. Nowoczesne Systemy Zarządzania, Zeszyt, No. 9, p. 263-290.

Gotz, M., Gracel, J. (2017) Przemysł czwartej generacji (Industry 4.0) - wyzwania dla badań w kontekście międzynarodowym. KNUV, No. 1(51), p. 217-235.

Hermann, M., Pentek, T. (2015). Design Principles for Industrie 4.0 Scenarios: A Literature Review. Technische Universität Dortmund Fakultät Maschinenbau. Working Paper, No. 01.

Informacja o wynikach kontroli świadczenia ustug publicznych przez niektóre organy administracji rzadowej przy zastosowaniu mediów elektronicznych (P/05/050; KGP/41012/05), nik.gov.pl.

Kaczmarski, L. (2009) Ewolucja pojęcia administracji publicznej w polskiej doktrynie prawa administracyjnego po II wojnie światowej. PWSZ IPiA Studia Lubuskie Tom V Sulechów, p. 219-245.

Kanaan, R., Abumatar, G., Lozi, M. (2019). Implementation of M-government: Leveraging Mobile Technology to Streamline the E-governance Framework. Journal of Social Sciences, Vol. 8, p. 495-508. DOI 10.25255/ jss.2019.8.3.495.508,

Kaniewska, M., Klimski, M. (2017). Global Policy of Eradicating Poverty. The Aspect of Education. Journal of Modern Science, Vol. 35(4), p. 283-300.

Kmiecik, P. (2015). Cyfryzacja administracji publicznej w Polsce, Nowa Strategia. Online: http://www.nowastrategia. org.pl/cyfryzacja/ [access: 14-04-2020].

Lielpeters, E. (2019). Engaging citizens in the decision-making process. Opportunities of digital democracy in Latvia. Regional Formation and Development Studies, Vol. 29, No. 3, p. 53-63.

Maślanek, J. (2014). Przemyst 4.0 - rewolucja czy ewolucja? Online: https://www.wnp.pl/artykuly/przemysl-4-0-rewolucja-czy-ewolucja,236764.html [access: 14-04-2020].

Micklethwait, J., Wooldridge, A. (2015). The Global Race to Reinvent the State. London: Penguin Press.

Moon, M. J. (2002). The evolution of E-Government among Municipalities: Rhetoric or Reality? Public Administration Review, July/August, Vol. 62, No. 4, p. 424-433.

O’Donnell, S., McQuillan, H., Malina, A. (2003). eInclusion: Expanding the Information Society in Ireland, Itech Research. Dublin.

Parysek, J. (2001). Podstawy gospodarki lokalnej. Poznań.

Romaniuk, P. (2018). The proper management of people's work manifests the implementation of humanistic management in the public administration. Journal of Modern Science, Vol. 36(1), p. 275-292.

Rzewuski, M. (2013). Register of wills as a source of information for potential heirs. Communication as a Measure of Protection and Limitation of Human Rights. Information in Relation to Human Rights, Univerzita Komenského v Bratislave, Právnická fakulta, Bratislava, p. 407-410.

Sitek, M. (2016). Agencje wykonawcze. W poszukiwaniu nowych narzędzi zarządzania (governance) integracją w Unii Europejskiej. Journal of Modern Science, Vol. 29(2), p. 95-108.

Sitek, M. (2017). Jakość prawa miejscowego jako warunek dobrze funkcjonującego samorządu. Journal of Modern Science, Vol. 32(1), p. 145-159.

Sitek, M., Such-Pyrgiel, M. (2018). Wpływ cyberkultury na prawa człowieka. Journal of Modern Science, Vol. 39(4), p. $201-215$.

Such, M. (2019). Człowiek $w$ dobie cyfrowej transformacji. Studium socjologiczne. Torun.

Schwab, K. (2016). The Fourth Industrial Revolution. The World Economic Forum. Cologny.

Szafrański, B., Weydmann, R. (2012). Nowy model świadczenia e-ustug publicznych. Wrocław.

Szczerbowski, J. (2019). Informatyzacja postępowania cywilnego. In M. Rzewuski (ed.). Postępowanie cywilne. Warszawa.

Śledziewska, K., Levai, A., Zięba, D. (2016). The use of e-government in Poland in comparison to other European Union Member States. Information Systems in Management, Vol. 5 (1), p. 119-130.

Wójcicka, M., Łęski, M. (2015). The concept of sustainable development in the UN activity. In M. Sitek, M. Wójcicka (eds.). Collective human rights, p. 341-354. Józefów: WSGE. ISBN 978-83-62753-73-4.

Ziemba, E. (2013). The Holistic and Systems Approach to the Sustainable Information Society. Journal of Computer Information Systems, Vol. 54 (1), p. 106-116. 


\section{Legal sources}

Polish law and documents:

Ustawa z dnia 6 września 2001 r. o dostępie do informacji publicznej (Dz. U. z 2019 r. poz. 1429).

Ustawa z dnia 17 lutego 2005 r o informatyzacji działalności podmiotów (Dz.U. z 2020 r. poz. 346).

Rozporządzenie Rady Ministrów z dnia 18 marca 2003 r. w sprawie utworzenia Ministerstwa Nauki i Informatyzacji i zniesienia urzędu Komitetu Badań Naukowych (Dz.U. 2003 nr 51 poz. 443).

Uchwała Sejmu Rzeczypospolitej Polskiej z 14 lipca 2000 roku w sprawie budowania podstaw społeczeństwa informacyjnego w Polsce (M.P. z 2000 r. Nr 22, poz. 448)

Uchwała nr 16 Rady Ministrów z dnia 5 lutego 2013 r. w sprawie przyjęcia Długookresowej Strategii Rozwoju Kraju. Polska 2030. Trzecia Fala Nowoczesności- Monitor Polski poz. 121 z 1 marca 2013 r.

Ministerstwo Nauki i Informatyzacji (2005) Strategia kierunkowa rozwoju informatyzacji Polski do roku 2013 oraz perspektywiczna prognoza transformacji społeczeństwa informacyjnego do roku 2020 z dnia 24 czerwca 2005.

Informacja o wynikach kontroli świadczenia usług publicznych przez niektóre organy administracji rządowej przy zastosowaniu mediów elektronicznych (P/05/050; KGP/41012/05) Warszawa, 2006.Online: https://www.nik.gov. pl/kontrole/wyniki-kontroli-nik/pobierz,px_2006118.pdf,typ,k.pdf

European law and documents:

Communication from the Commission to the European Parliament. The Council, the European Economic and Social Committee and the Committee of the Regions the European eGovernment Action Plan 2011-2015 Harnessing ICT to promote smart, sustainable \& innovative Government, $\operatorname{COM}(2010) 743$ final.

Communication of 8 December 1999 on a Commission initiative for the special European Council of Lisbon, 23 and 24 March 2000 - eEurope - An information society for all [COM(1999) 687 final - not published in the Official Journal].

Communication from the Commission to the European Parliament. The Council, the European Economic and Social Committee and the Committee of the Regions Eu eGovernment Action Plan 2016-2020 Accelerating the digital transformation of government COM/2016/0179 final.

Green Paper on the Convergence of the Telecommunications, Media and Information Technology Sectors, and the Implications for Regulation, COM(97)623, Brussels (1997).

E-Europe 2002. Impact and Priorities. A communication to the Spring European Council in Stockholm, 23-24 March 2001, Brussels (2001 a).

E-Europe 2002. An Information Society for All. Action Plan prepared by the Council and the European Com- mission for the Feira European Council Brussels (2001 b).

EUROPA 2020 - A strategy for smart, sustainable and inclusive growth.

Europe 2020: the European Union strategy for growth and employment (COM(2010) 2020 final 3.3.2010).

EU eGovernment Action Plan 2016-2020 Accelerating the digital transformation of government COM(2016) 179 final.

Supporting implementation at local and regional level. eGovernment Action Plan 2016-2020. Online: https:// ec.europa.eu/digital-single-market/en/supporting-implementation-local-and-regional-level-egovernment-actionplan-2016-2020 [access: 14-04-2020].

Local legislation and documents:

Uchwała nr 193/XXX/09 uchwała w sprawie przystąpienia Powiatu Otwockiego do projektów kluczowych realizowanych przez Samorząd Województwa Mazowieckiego w ramach Regionalnego Programu Operacyjnego Województwa Mazowieckiego 2007-2013.

Uchwała 34/V/19 Rady Powiatu w Otwocku z dnia 28 marca 2019 r. w sprawie dopuszczenia zapłaty należności stanowiących dochody budżetu powiatu otwockiego za pomocą innego instrumentu płatniczego w tym instrumentu na którym przechowywany jest pieniądz elektroniczny.

Strategia rozwoju Powiatu Otwockiego na lata 2014-2020. Online: https://www.bip.powiat-otwocki.pl/ plik,10611,strategia-rozwoju-powiatu-otwockiego-na-lata-2014-2020.pdf [access: 16-04-2020].

Strategia Zarządzania Zasobami Ludzkimi w Powiecie Otwockim z 2013. Online: https://www.bip.powiat-otwocki.pl/ plik,8965,strategia-zarzadzania-zasobami-ludzkimi-w-starostwie-powiatowym-w-otwocku.pdf [access: 16-04-2020].

Regulamin organizacyjny Starostwa Powiatowego. (2016). Online: https://www.bip.powiat-otwocki.pl/ plik,6500,regulamin-organizacyjny-starostwa-powiatowego-w-otwocku.pdf [access: 16-04-2020].

Powiat Otwocki, strona internetowa, e-usługi. Online: http://www.powiat-otwocki.pl/urzad-starostwa/zawartosc/50/ [access: 16-04-2020].

Powiat Otwocki - Dane demograficzne, GUS, 31.XII.2017. Online: https://www.polskawliczbach.pl/powiat_otwocki [access: 16-04-2020]. 


\title{
VIEŠOJO ADMINISTRAVIMO PASLAUGŲ \\ S KA I T M E N I N I M A S LEN KI JO JE, REA GUOJANT I PRAMONË 4.0 REVOLIUCIJA IR ATSIŽVELGIANT I VIETOS SAVIVALDĄ
}

\author{
Magdalena Sitek, Iwona Florek, Bronislaw Sitek \\ Euroregioninès ekonomikos universitetas Józefóve, Varšuvoje (Lenkija), \\ Socialinių ir humanitarinių mokslų universitetas Varšuvoje (Lenkija)
}

\section{Santrauka}

Straipsnyje aptariamas pramonės revoliucijos 4.0, t. y. suskaitmenintos pramonès, paremtos moderniosiomis informacinėmis technologijomis, ir darnaus vystymosi bei loginès jų pasekmès, t. y. suskaitmeninto viešojo administravimo būtinybès, tarpusavio santykis. Kompiuterizuojant administravimą, išnaudotos 4.0 pramonès teikiamos galimybès, igyvendinant darnaus vystymosi koncepcijos idèjas. Autoriai pateikẻ praktinį skaitmeninio administravimo koncepcijos įgyvendinimo pavyzdį, remdamiesi Otwocko apskrities pavyzdžiu.

Šio tyrimo rezultatas - viešojo administravimo paslaugų pritaikymas vykstantiems pokyčiams, kurie atsirado ịgyvendinant pramonés revoliucijos 4.0 nulemtą skaitmeninimą. Rezultatai pateikti pasitelkiant vieną Otwocko (Lenkijoje) apskritį. Galima teigti, kad e. administravimas yra tik šalies plètros koncepcijos ilgalaikèje perspektyvoje priemonè, atsižvelgiant ị dabartinių ir ateities kartų poreikius.

Kadangi straipsnis yra tarpdisciplininio pobūdžio - teisinio ir regioninio vystymosi aspektų derinys, taikomi abiejų disciplinų tiriamieji metodai. Pagrindinis - teisès nuostatų ir ịvairių dokumentų, įskaitant nacionalines ir vietos e.administravimo plètros strategijas, analizè. Kitas tyrimo metodas - lyginamoji viešojo administravimo pokyčių analizè ir aprašymas, remiantis Otwocko apygardos pavyzdžiu, lyginant su likusia šalies dalimi.

Straipsnyje siekta parodyti dabartinę e.piliečio koncepcijos įgyvendinimo padètį Lenkijoje ir kokių naujų iniciatyvų imamasi. Vis dèlto svarbiausia išanalizuoti piliečių elektroninius ryšius su vietos valdžios administracija, remiantis Otwocko apskrities pavyzdžiu, igyvendinant pramonés revoliuciją 4.0. Atlikus tyrimą pateikiama rekomendacijų, kaip viešaji administravimą pritaikyti pokyčiams, kurie virtualiame pasaulyje kilo vykstant pramonés revoliucijai 4.0. Tyrimo rezultatai gali būti taikomi lyginamiesiems tyrimams kitose Lenkijos ir Europos Sajungos šalių savivaldybėse.

PAGRINDINIAI ŽODŽIAI: skaitmeninimas, viešasis administravimas, pramonès revoliucija 4.0, Lenkija.

JEL KLASIFIKACIJA: D83, H83.

Received: 2020-04-19

Revised: 2020-05-20

Accepted: 2020-05-25 